\title{
Structural and Sedimentary Characteristics of Hydrocarbon-Rich Sags in Lacustrine Sub-Basin of Half Graben Type, Pearl River Mouth Basin, South China Sea
}

\author{
Lei He ${ }^{1,2}$, Xiaolong Wang1,2,3*, Ningbo Cai ${ }^{4}$, Jie $Q u^{1,2}$, Xiong Zhu ${ }^{1,2}$, Daomao Lin ${ }^{1,2}$ \\ ${ }^{1}$ Key Laboratory of Exploration Technologies for Oil and Gas Resources (Ministry of Education), Yangtze University, Wuhan, \\ China \\ ${ }^{2}$ School of Geophysics and Oil Resource, Yangtze University, Wuhan, China \\ ${ }^{3}$ Hubei Cooperative Innovation Center of Unconventional Oil and Gas, Wuhan, China \\ ${ }^{4}$ The Coal Geological Exploration Institute of Hunan Province, Changsha, China \\ Email: *wxlong@yangtzeu.edu.cn
}

How to cite this paper: He, L., Wang, X.L., Cai, N.B., Qu, J., Zhu, X. and Lin, D.M. (2019) Structural and Sedimentary Characteristics of Hydrocarbon-Rich Sags in Lacustrine Sub-Basin of Half Graben Type, Pearl River Mouth Basin, South China Sea. Open Journal of Yangtze Gas and Oil, 4, 194-211.

https://doi.org/10.4236/ojogas.2019.43015

Received: January 19, 2019

Accepted: July 22, 2019

Published: July 25, 2019

Copyright $\odot 2019$ by author(s) and Scientific Research Publishing Inc. This work is licensed under the Creative Commons Attribution International License (CC BY 4.0).

http://creativecommons.org/licenses/by/4.0/

\section{Abstract}

Pearl River Mouth Basin undergoes complex tectonic evolution processes and forms lacustrine, transitional and marine sediments. Drilling shows that there exist large petroleum reserves in the hydrocarbon-rich sags of Pearl River Mouth Basin, South China Sea. To reduce the risk, the exploration, structural and sedimentary characteristics of the hydrocarbon-rich sags should be identified and described. Drilling, seismic, and microfossil data are integrated to interpret the structural and sedimentary evolution of the hydrocarbon-rich sags in Pearl River Mouth Basin. By analyzing the tectonic and sedimentary evolutionary characteristics, three conclusions may be drawn: 1) The present regional tectonic characteristics of the $\mathrm{PRMB}$ are formed by mutual interactions of the Eurasian Plate, Pacific Plate, Philippine Plate and Indian Plate. During the Paleocene to early Eocene and late Eocene and early Oligocene, the PRMB is at the rifting stage. During the late Oligocene, the PRMB was at the rifting-depression transitional stage. After the Oligocene, the PRMB is at the depression stage. 2) Tectonic conditions control the sedimentation process in the hydrocarbon-rich sags. During the lacustrine sedimentation stage, synsedimentary faults and intense faulting control the sedimentation. During the transitional sedimentation stage, weak fault activity influences the deposition process in the hydrocarbon-rich sags. During the marine sedimentation stage, weak fault activity and depression activity control the deposition process in the hydrocarbon-rich sags. 3) Tectonic evolution affects the deposition process. The lacustrine, transitional and marine sedimentation corresponds to different tectonic conditions. The lacustrine sedimentation is 
formed under fault activity during the rifting stage. The transitional sedimentation is formed under weak fault activity during the late rifting stage. The marine sedimentation is formed under weak fault activity and depression activity during the rifting-depression and depression stages. 4) The half graben is beneficial for the formation of lacustrine source rocks, which is responsible for the hydrocarbon-rich sag. Therefore the half graben mode contributes to the hydrocarbon-rich sags.

\section{Keywords}

Half Graben, Lacustrine Sedimentation, Transitional Sedimentation, Marine Sedimentation, Hydrocarbon-Rich Sag, Pearl River Mouth Basin

\section{Introduction}

Different tectonic conditions develop different sedimentary environments [1]. Different sedimentary environments determine oil and gas reservoirs [2]. Pearl River Mouth Basin (PRMB) of the South China Sea is a discrete continental margin basin in which lacustrine, transitional and marine sedimentation occurs [3] [4]. An empirical knowledge of long-term hydrocarbon exploration suggests there are many hydrocarbon-rich sags in the PRMB [5] [6]. In addition, the structural and sedimentary characteristics and evolution are key factors in controlling the distribution of the hydrocarbon-rich sags in the PRMB [7] [8]. The structural and sedimentary evolution of the hydrocarbon-rich sags in the PRMB is of significant academic and economic interest because they can help us better understand tectonic events, climatic changes, and magmatic activity along convergent plate margins [7] [9] [10]. Therefore, studies on the structural and sedimentary characteristics have important implications for hydrocarbon exploration in PRMB [4] [11].

Although several hydrocarbon-rich sags have been recognized in the PRMB after 30 years of exploration and have attracted attention to study the tectonics and sediments of the basin [10], there are still some debates about the evolution of these hydrocarbon sags. To date, few wells have been drilled, and hydrocarbon resources have seldom been recognized in the basin; there has even been a lack of comprehensive analysis of the structural and sedimentary characteristics of these hydrocarbon-rich sags, which has limited further exploration for hydrocarbon resources. On the foundation of current exploration progress in the hydrocarbon-rich sags of the PRMB, a study is carried out by integrating geophysical data and microfossil data from seismic lines and wells. The purposes of this work are to analyze the formation and evolutionary characteristics of the sags, summarize the tectonic history of the fault systems, and evaluate the depositional setting of the hydrocarbon-rich sages in the PRMB.

In this study, the structural evolution and sedimentary characteristics including the basin evolution, features of the structural units within the basin, fault features, depositional environments and facies are analyzed. Based on these re- 
sults, the controls of structural and sedimentary evolution on the formation of the hydrocarbon-rich sags are discussed. Finally, the tectonic evolution and the deposition process of the hydrocarbon-sags are summarized, which may be of significance for future exploration in this region and the deep-water zone in the PRMB and some other places over the world that has similar settings.

\section{Geological Setting}

PRMB is one of the petroliferous Cenozoic rift basins in the north of the continental margin of South China Sea [10] (Figure 1). Tectonically, the basin is located in the south district of the Huanan Island block and on the east side of the Indosinian land block. Its evolution is affected by the movements of the Myanmar-Thailand-Malaysia land block, India-Australia land block and Philippine land block [4] (Figure 1(b)).

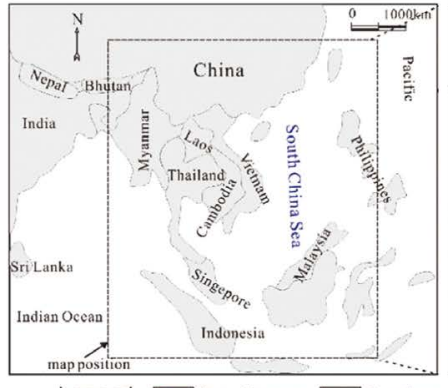

Legend $\square$ Deep Fracture $\square$ Contin margin basin, South China Sea

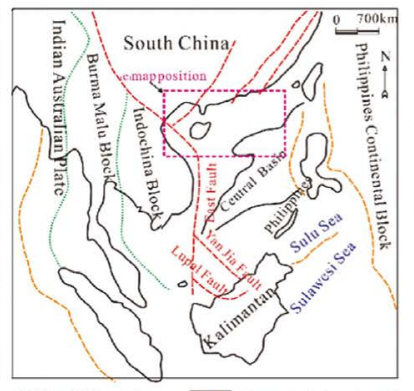

(b) Structural location of the northern continental margin basin, South China Sea

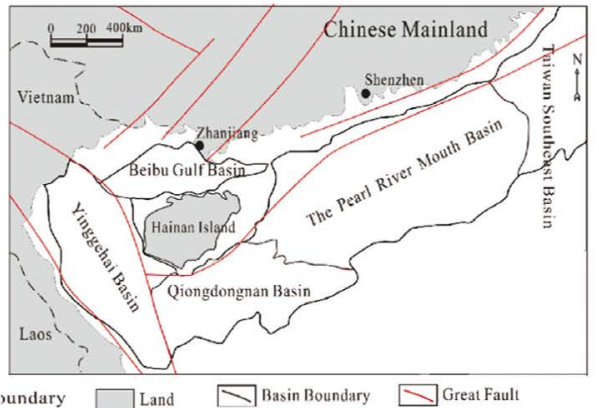

(c) Location of PRMB

Figure 1. The simplified structure position of PRMB.

PRMB has unique alternating uplifts and sags. Generally, the basin can be divided from north to south into the Northern Uplift Zone, Northern Geotectogene, Central Uplift Zone, Southern Geotectogene and Southern Uplift Belt and into blocks in the E-W direction [12]. There are three depressions in PRMB, including the Zhu I Depression, Zhu II Depression and Zhu II Depression [12]. The Northern Geotectogene contains the Zhu I Depression and Zhu III Depression (Figure 2), while the Zhu II Depression is located in the Southern Geotectogene.

The basin has integrated Cenozoic sequences from bottom to top. Eight second-order stratigraphic units are distributed in a basin-scale region, including Paleocene Shenhu Formation, Eocene Wenchang Formation, Oligocene Enping Formation and Zhuhai Formation, Miocene Zhujiang Formation, Hanjiang Formation, and Yuehai Formation and Pliocene Wanshan Formation [12]. Three source rock series include the lacustrine source rocks of Wenchang Formation, the transitional source rocks of the Enping Formation, and the marine source rocks of the Zhuhai, Zhujiang, and Hanjiang Formations in the PRMB [4] [5]. There are also plentiful reservoir and seal rocks including the Wenchang, Enping, Zhuhai, Zhujiang, and Hanjiang Formations [4] [12]. In this paper, the tectonic and sedimentary characteristics and the evolution of these hydrocarbon-sags are discussed. 


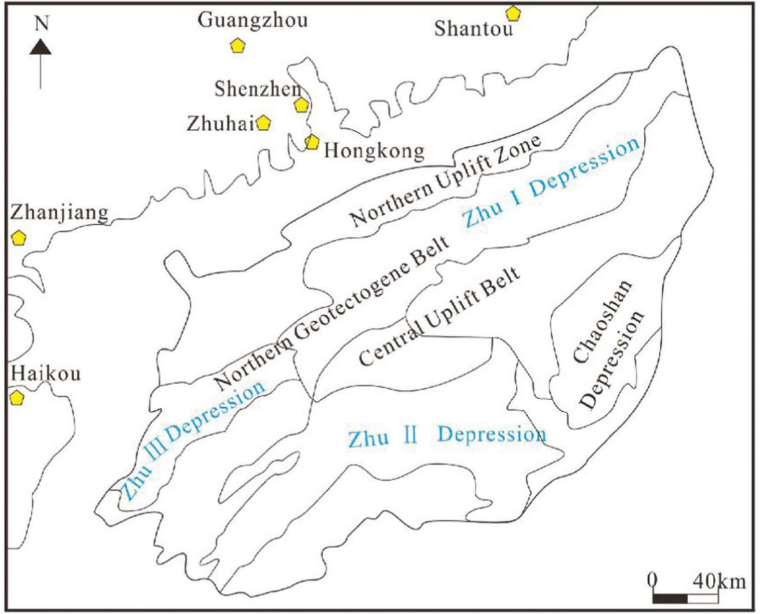

(a) The structural units in PRMB

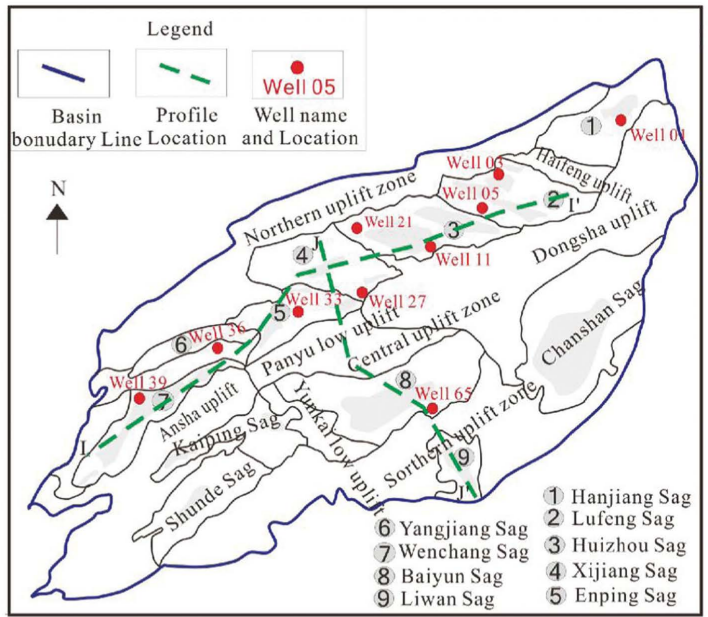

(b) hydrocarbon-rich sags, Location of seismic lines and wells in PRMB

Figure 2. The structural units, hydrocarbon-rich sags, Location of seismic lines and wells in PRMB.

\section{Data and Methods}

Drilling, well logs, microfossil and seismic data are integrated to document the tectonic and sedimentary characteristics of the PRMB. Drilling and well logs from 10 wells are examined and described thoroughly to identify different lithologies, sedimentary structures and facies. Seismic profiles are combined to interpret the features of faults and sequences. All data are finally used to document the control of tectonics on sedimentation in the PRMB.

Expansion Index $(E I)$, a ratio derived by dividing the hanging wall stratal thickness and by the adjacent footwall stratal thickness for a given stratigraphic unit, is applied to identify periods of significant fault growth and activity. The thicknesses of the hanging wall and adjacent footwall are based on the time-depth conversion and stratigraphic interpretation. In general, the $E I$ of reverse faults is $<1$, the $E I$ of normal fault is $>1$, where $E I$ is $=1$, the fault is interpreted to be dormant [13]. $E I$ is obtained by calculating the ratio of the thickness of the footwall and the thickness of the hanging wall (Table 1).

Table 1. The EI comparison table of the faults of Wenchang and Enping Formations in the half graben Fault Names.

\begin{tabular}{ccccccccccccccc}
\hline Profiles & & & & \multicolumn{1}{c}{ EI/1 } & & & & & & \\
\hline & FN & F3 & F4 & F5 & F6 & F7 & F8 & F9 & F10 & F11 & F12 & & & \\
$A A^{\prime}$ & EP & BF & T & 1.06 & T & BF & W & W & W & BF & 1.05 & & & \\
& WC & BF & 1.16 & T & T & BF & 1.97 & 3.72 & 5.33 & BF & 2.41 & & & \\
& FN & F1 & F2 & F3 & F4 & F7 & F8 & F9 & F10 & F11 & & & & \\
$B B$ & EP & BF & 1.03 & 1.04 & T & BF & T & T & T & BF & & & & \\
& WC & BF & 1.15 & 1.29 & 2.49 & BF & 1.27 & 1.13 & 1.33 & BF & & & & \\
& FN & F3 & F4 & F5 & F6 & F7 & F8 & F9 & F10 & F11 & F12 & F13 & F14 & F15 \\
& EP & BF & 1.01 & 1.03 & 1.02 & T & 1.05 & 1.05 & 1.01 & T & T & 1.03 & 1.04 & BF \\
\hline
\end{tabular}




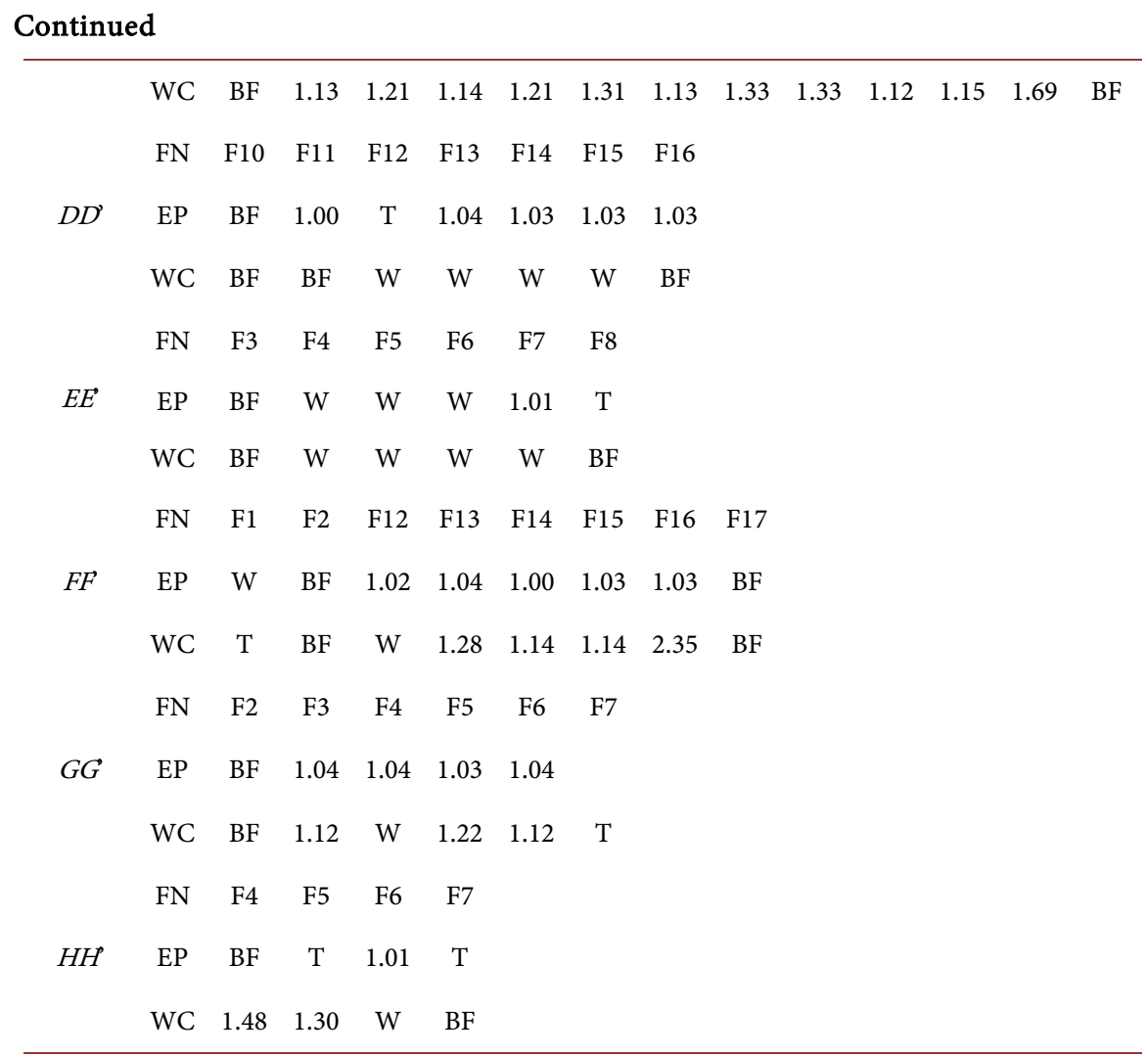

EP: Enping Formation EI; WC: Wenchang Formation EI; BF: Boundary Fault of half graben; T: Fault Terminal within Formation; W: There is no fault in this layer.

Twenty-one mudstone samples are selected from Well 05 within Wenchang, Enping and Zhuhai Formations to characterize the sedimentary settings. All samples are crushed and processed according to the Chinese Oil and Gas Industry Standard (GB/T) 19145-2003. The microfossil data for four wells are also collected from China National Offshore Oil Corporation Research Institute.

\section{Results and Discussion}

\subsection{Characteristics of Faults}

\subsubsection{Structure Units and Features}

Many major faults develop in the PRMB during the Paleocene to early Oligocene (Figure 3). The trend of major faults is approximately east-west in Hanjiang Sag, Lufeng Sag, Huizhou Sag, Xijiang Sag, Enping Sag, Baiyun Sag and Liwan Sag (colored red in Figure 3). Since the tectonic stress is transverse to the strike, the major stress direction is approximately north-south. Meanwhile, the trend of the major faults is NE or ENE in the Yangjiang Sag and Wenchang Sag with the major stress direction approximately NW. According to previous research, the major faults of the PRMB are originated from tensile stress [9].

During the Paleocene to early Oligocene, the sedimentary process in hydrocarbon-rich sags is mainly controlled by synsedimentary normal faults because the downthrown block is thicker than the upthrown block. Profile IP directly shows that the hydrocarbon-rich sags are characterized by alternating rises and 
sags because of the rifting and synsedimentary faults (Figure 4(a)). These faults divide the hydrocarbon-rich sags into several half grabens where the Wenchang and Enping Formations are deposited. In Xijiang and Lufeng Sags, one edge of the half graben is controlled by normal faults, while the others are controlled by the onlap of the basement. The thicknesses of Wenchang and Enping Formations near the deepest normal faults downdip are significantly larger than those of onlap contacts. On the other hand, in Enping Sag, Huizhou Sag and Wenchang Sag, the edges of the half grabens are controlled by normal faults, and the thicknesses of the downthrown blocks are greater than those of the upthrown blocks. During the late Oligocene, there are few active synsedimentary normal faults in the hydrocarbon-rich sags, and at this rifting-depression stage the evolution is less influenced by faults.

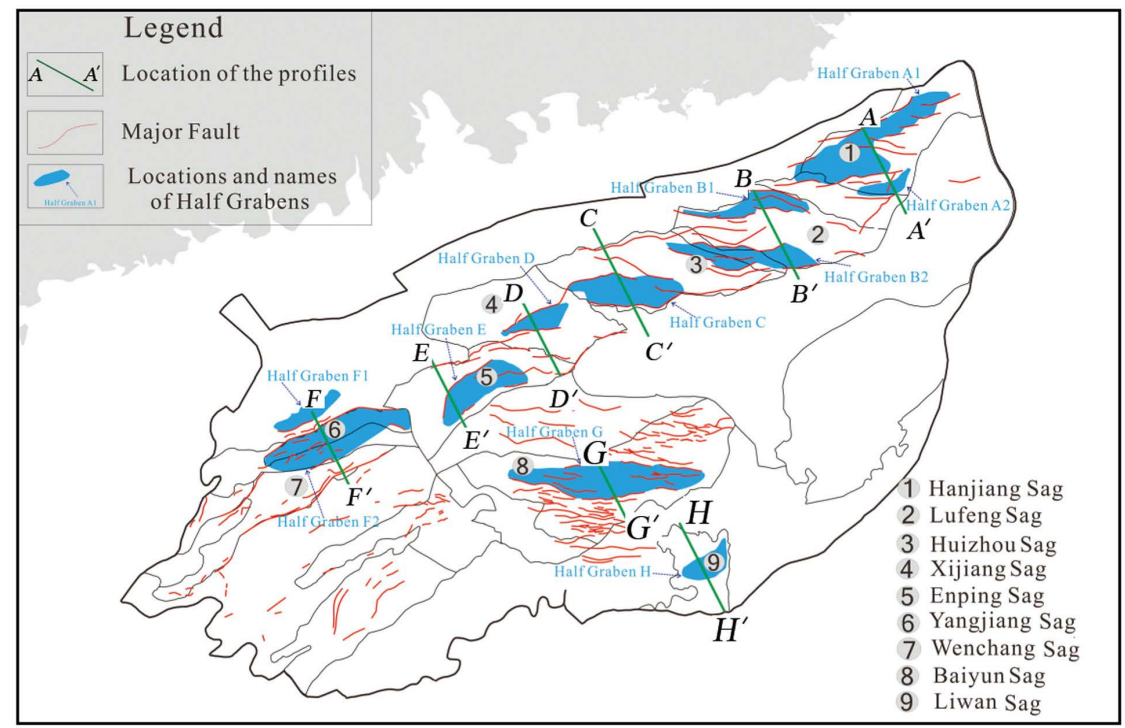

Figure 3. Distributions of major faults during Eocene in the PRMB.

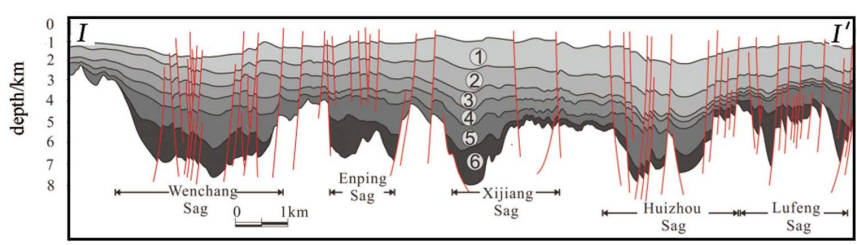

(a) $I I^{\prime}$ profile

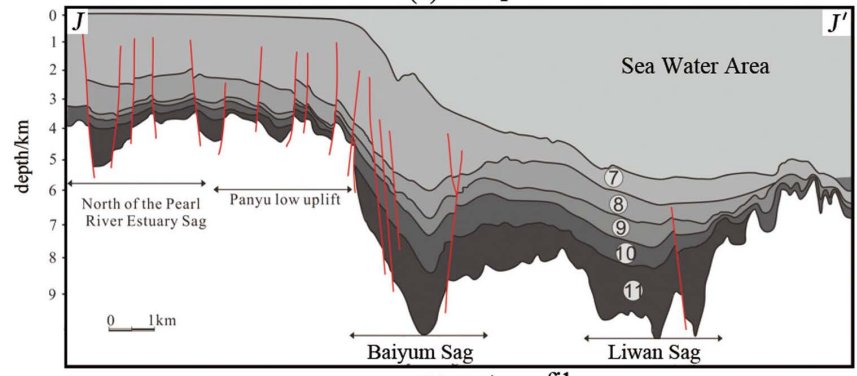

(b) $J J^{\prime}$ profile
Legend

(1) Yuehai Formation

(2) Hanjiang Formation (3) Zhujiang Formation (4) Zhuhai Formation (5) Enping Formation (6) Wenchang Formation (7) Medium system-Quaternary (8) Zhujiang Formation (9) Zhuhai Formation (10) Enping Formation (10) Wenchang Formation $\checkmark$ Great Fault

Figure 4. Interpreted profile shows the tectonic background in hydrocarbon-rich sags in PRMB. The location of the profile is shown in Figure 2(b) (Zhu et al., 2010). 
Profile $J J^{\prime}$ shows that during the Paleocene to early Oligocene, many major faults are developed in Baiyun Sag and Liwan Sag (Figure 4(b)). In addition, the sedimentation in Baiyun Sag is controlled by synsedimentary normal faults because the downthrown block is thicker than the upthrown block. The synsedimentary normal faults divide Baiyun Sag into half grabens. In addition, Liwan Sag is less influenced by faults with limited fault development. During the late Oligocene and Miocene, Baiyun and Liwan Sags are at the rifting-downwarp stage and the heatsink stage, which are less influenced by faults.

\subsubsection{Fault Characteristics in the Rifting and Depression Setting}

Three phases of activity can be interpreted for fault growth in the sags of the PRMB. The first array of faults terminates upward in Wenchang Formation and the bottom of Enping Formation. These features are easy to interpret due to the large displacement of reflectors. This pattern indicates that the phase of faulting occurs during the Paleocene to early Oligocene, and the thickness of the downthrown block is thicker than that of the upthrown block. The second array of faults terminates upward in Enping Formation and the bottom of Zhuhai Formation with some extending downward to the basement. Most of the faults developed during this period are reactivated faults during the late Oligocene. The third array of faults is developed after the deposition of Zhuhai Formation when the PRMB is at the rifting-depression transitional stage and the depression stage.

In these profiles many half-grabens can be revealed, whose boundaries are mainly the high-angle faults. The distribution of the half graben can be disclosed in the plane based on the interpretation of a number of vertical seismic profiles (Figure 5 and Figure 6). In plane view, there are 11 half grabens (half grabens A1, A2, B1, B2, C, D, E, F1, F2, G, H) during deposition of Wenchang Formation in the hydrocarbon-rich sags (Figure 3). In these half grabens, $E I$ of these faults of Wenchang Formation is generally greater than $1.10(E I=1.12-5.33)$ (Table 1). It indicates that the faults of Wenchang Formation are in a period of vigorous activity in these half grabens. $E I$ of these faults of Enping Formation is generally smaller than $1.04(E I=1.00-1.04)$ in these half grabens. It indicates that these faults of Enping Formation are less active or inactive in these half grabens. Most of the faults formed during Enping Formation are reactivations of faults from Wenchang Formation.

\subsection{Seismic Sequences and Sedimentary Facies}

Geobiological component data from Well 11 (Figure 7) are collected to indicate the depositional setting. Wenchang Formation contains a large amount of phytoplanktons mainly including Pediastrum, Chlorella and Botryococcus, which reflect lacustrine sedimentation. Fern seeds have relatively small contents. In contrast, there is a sharp decrease in the level of phytoplankton in Enping Formation, and only several Pediastrum, Botryococcus and Chlorella are preserved in the strata. However, fern seeds and arboreal pollen still account for a large proportion. Marine Dinophyceae are preserved in Zhuhai Formation, which are 
not found in Wenchang or Enping Formations. The presence of marine Dinophyceae may reveal a marine sedimentary environment during the late Oligocene [14].

Well correlation profiles (Figures 8-10) show that the lithology during the sedimentary period of Wenchang Formation is mainly gray-black mudstones, gray and linen argillaceous siltstone, and sandstone. The sedimentary facies of Wenchang Formation are shown in a single well as middle-deep lacustrine, fluvial, limnetic, shallow lacustrine and shore shallow lake facies.

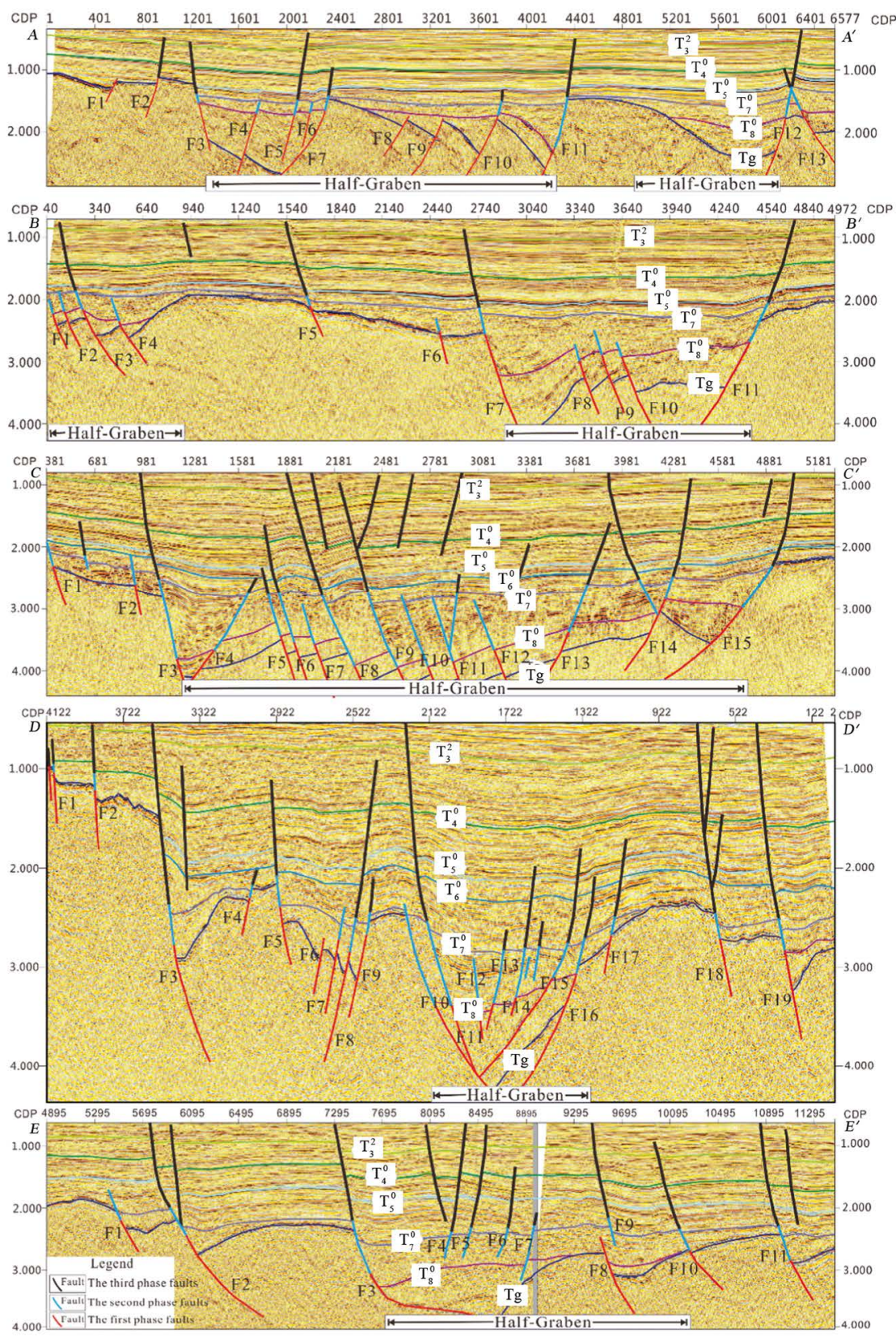

Figure 5. Interpreted seismic profile shows tectonic background in hydrocarbon-rich sags in the PRMB. The locations of the profile $A A^{\prime}, B B^{\prime}, C C, D D^{\prime}, E E$ are shown in Figure 3 . 


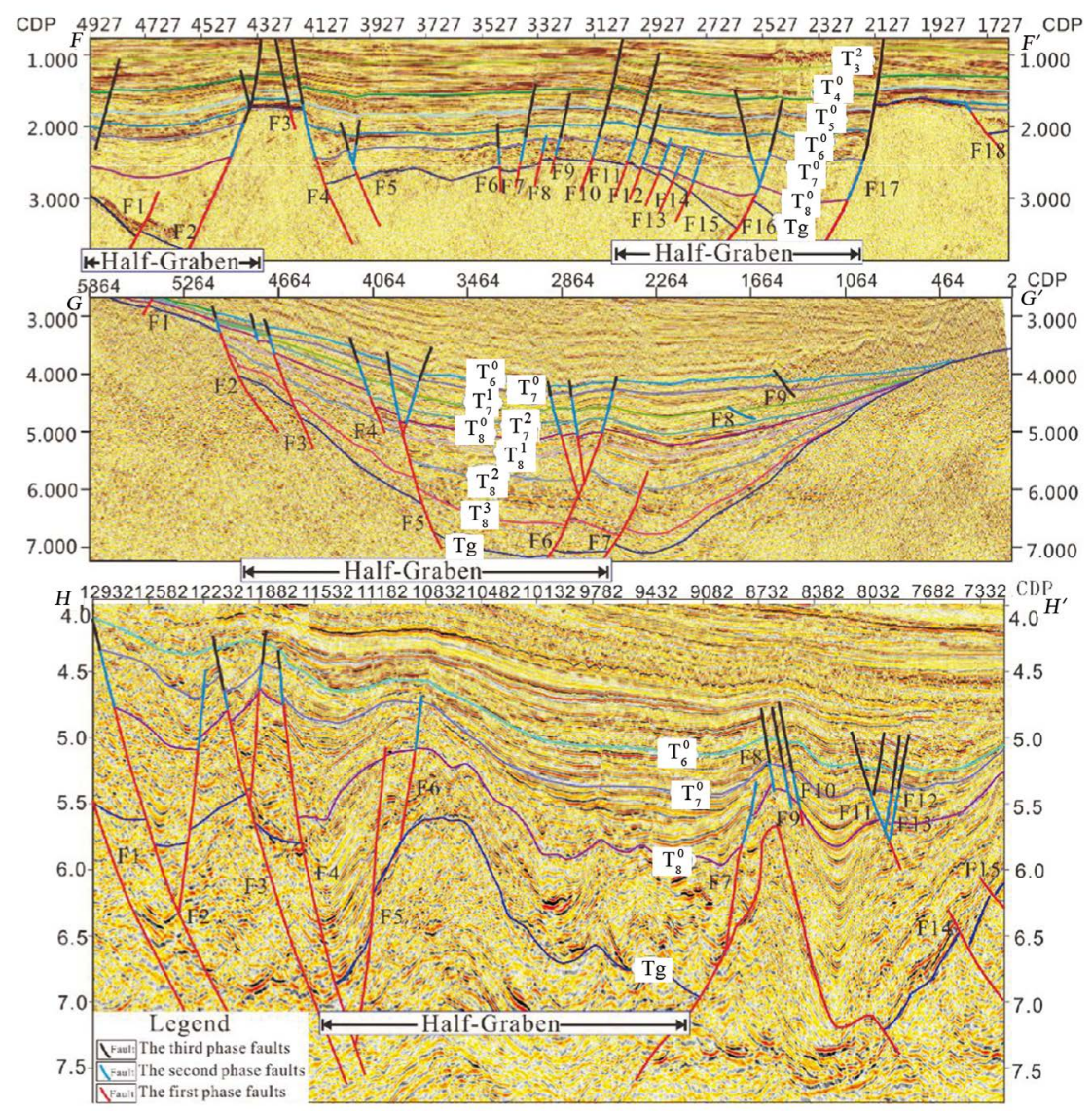

Figure 6. Interpreted seismic profile shows tectonic background in hydrocarbon-rich sags in the PRMB. The locations of the profile $F F, G G, H H^{\prime}$, are shown in Figure 3.

\begin{tabular}{|c|c|c|c|c|c|c|c|c|c|c|}
\hline$\stackrel{\pi}{\pi}$ & $\underset{\text { depth }}{\mathrm{m}}$ & $\begin{array}{c}\text { Fern seed } \\
/ \%\end{array}$ & $\begin{array}{c}\text { Alboreal } \\
\text { pollen } \\
/ \%\end{array}$ & $\begin{array}{c}\text { Phytoplankton } \\
/ \%\end{array}$ & $\begin{array}{c}\text { Pediastrum } \\
1 \%\end{array}$ & $\begin{array}{c}\text { Chlorella } \\
/ \%\end{array}$ & $\begin{array}{c}\text { Bosedinia } \\
/ \%\end{array}$ & $\begin{array}{c}\text { Marine } \\
\text { Dinophyceae } \\
/ \%\end{array}$ & $\underset{/ \%}{\text { Concentricystes }}$ & $\begin{array}{c}\text { Acritarchs } \\
/ \%\end{array}$ \\
\hline$n$ & & $\begin{array}{lll}20 & 0 & 20\end{array}$ & $\begin{array}{lll}50 & 0 & 50 \\
\end{array}$ & $0 \quad 30$ & $\begin{array}{lll}10 & 0 & 10 \\
\end{array}$ & $\begin{array}{lll}25 & 0 & 25 \\
\end{array}$ & $\begin{array}{lll}10 & 0 & 10 \\
\end{array}$ & $\begin{array}{lll}6 & 0 & 6 \\
\end{array}$ & $\begin{array}{lll}0.6 & 0 & 0,6 \\
\end{array}$ & $10 \quad 0 \quad 10$ \\
\hline 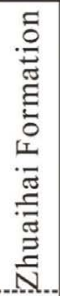 & $3200-$ & $>$ & 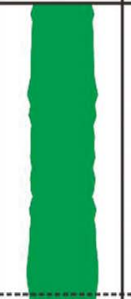 & 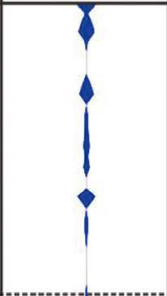 & + & & & 25 & & $\begin{array}{l}1 \\
8 \\
8\end{array}$ \\
\hline 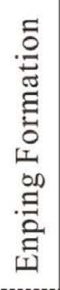 & $3800-$ & & & 1 & 1 & & & & $\longrightarrow$ & \\
\hline 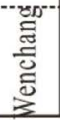 & $4400-$ & & & & & & & & & - \\
\hline
\end{tabular}

Figure 7. Evolution of geobiological components during Eocene and Oligocene (The micropaleontology data are derived from Well 11). 


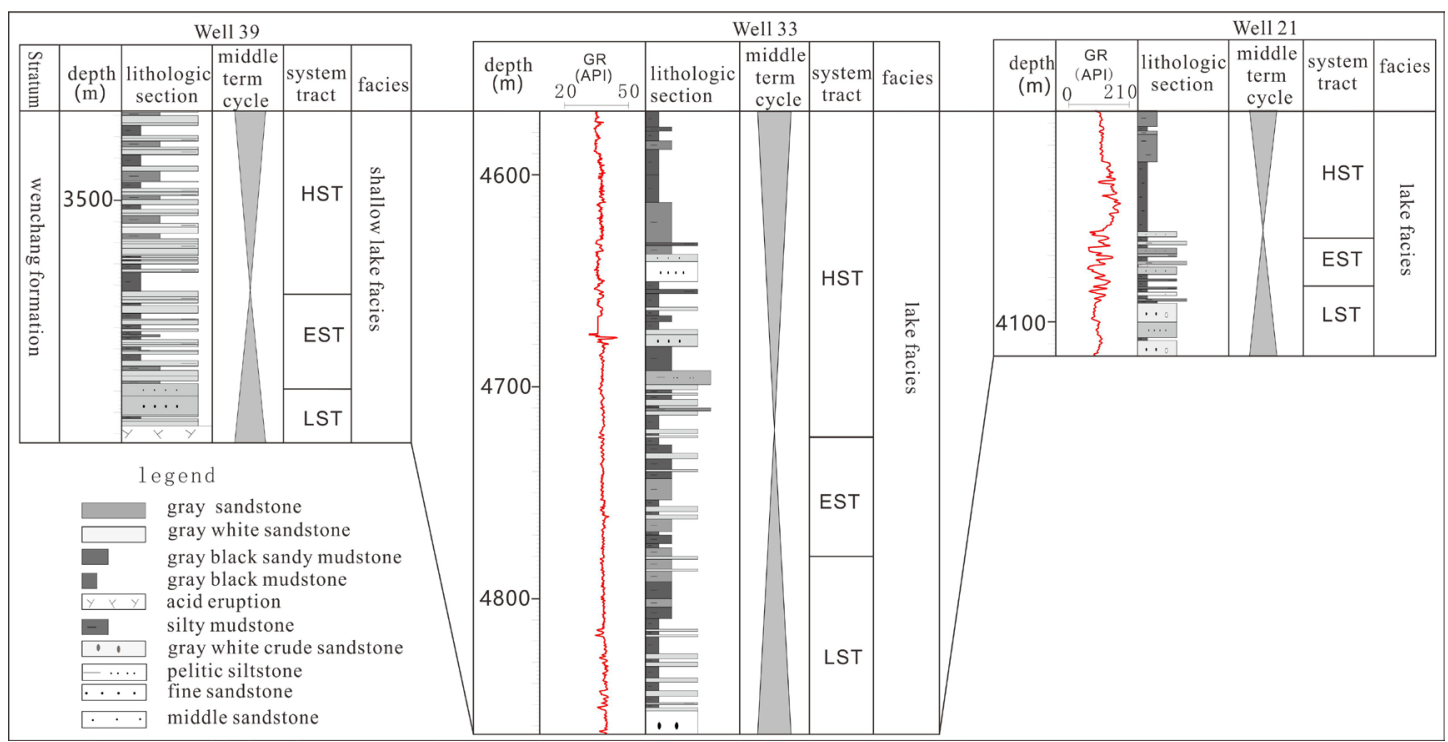

Figure 8. Wells correlation profiles show the lithologic and sedimentary characters in RPMB (the locations of Well 39, Well 33 and Well 21 are shown in Figure 2).

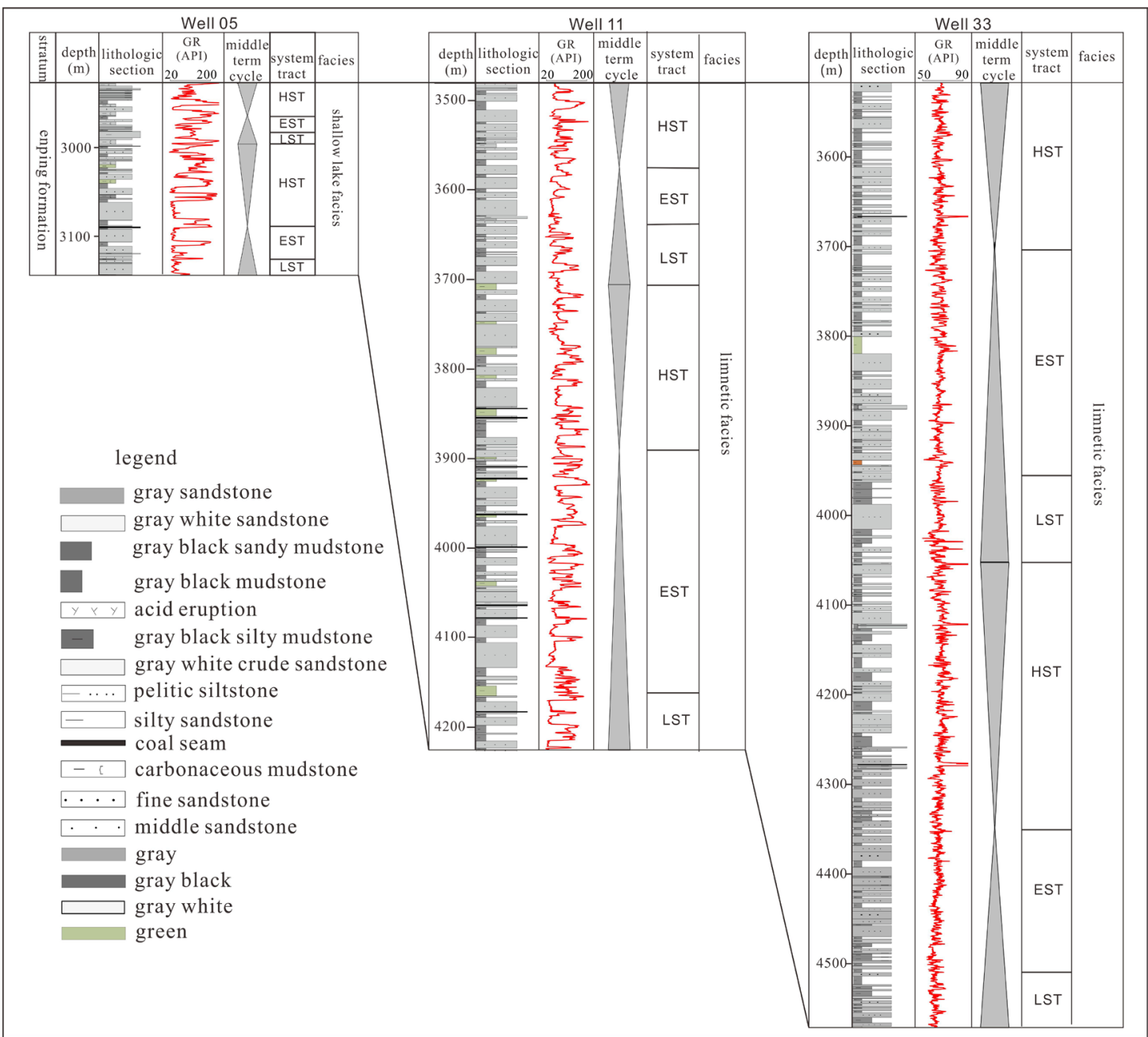

Figure 9. Well correlation profiles show the lithologic and sedimentary characters in RPMB (the locations of Well 05, Well 11 and Well 33 are shown in Figure 2). 


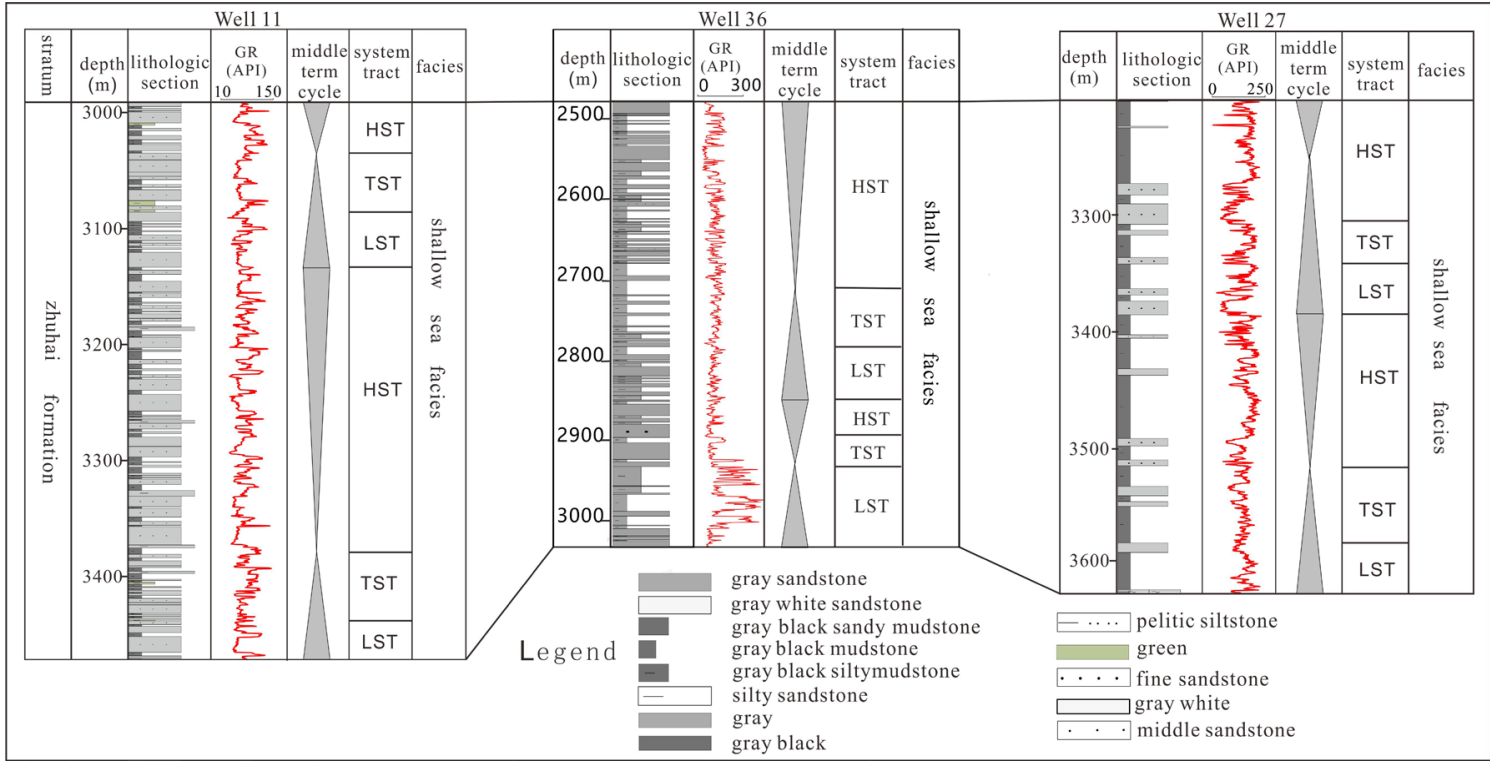

Figure 10. Well correlation profiles show the lithologic and, sedimentary characters in RPMB (the locations of Well 11, Well 36 and Well 27 are shown in Figure 2).

By integrating observations (from drilling data with analyses of well lithology and wireline logs), the depositional facies of Wenchang, Enping and Zhuhai Formations can be accurately defined, i.e., lacustrine, transitional and marine facies, respectively. During the Eocene, the main facies categories are middle-deep lacustrine facies distributed in the deep area at the footwall of large-scale faults and shallow lacustrine facies, delta and fan delta near the faults (Figure 11). In Liwan, Baiyun, Huizhou and Xijiang Sags, middle-deep lake facies are widespread. During the early Oligocene, the major sedimentary facies in the hydrocarbon-rich sags of PRMB are delta, fluvial, limnetic, shallow lacustrine and shore shallow lake (Figure 12). During the late Oligocene, shallow shore sea and coastal plain environments are dominated in the hydrocarbon-rich sags of the PRMB (Figure 13).

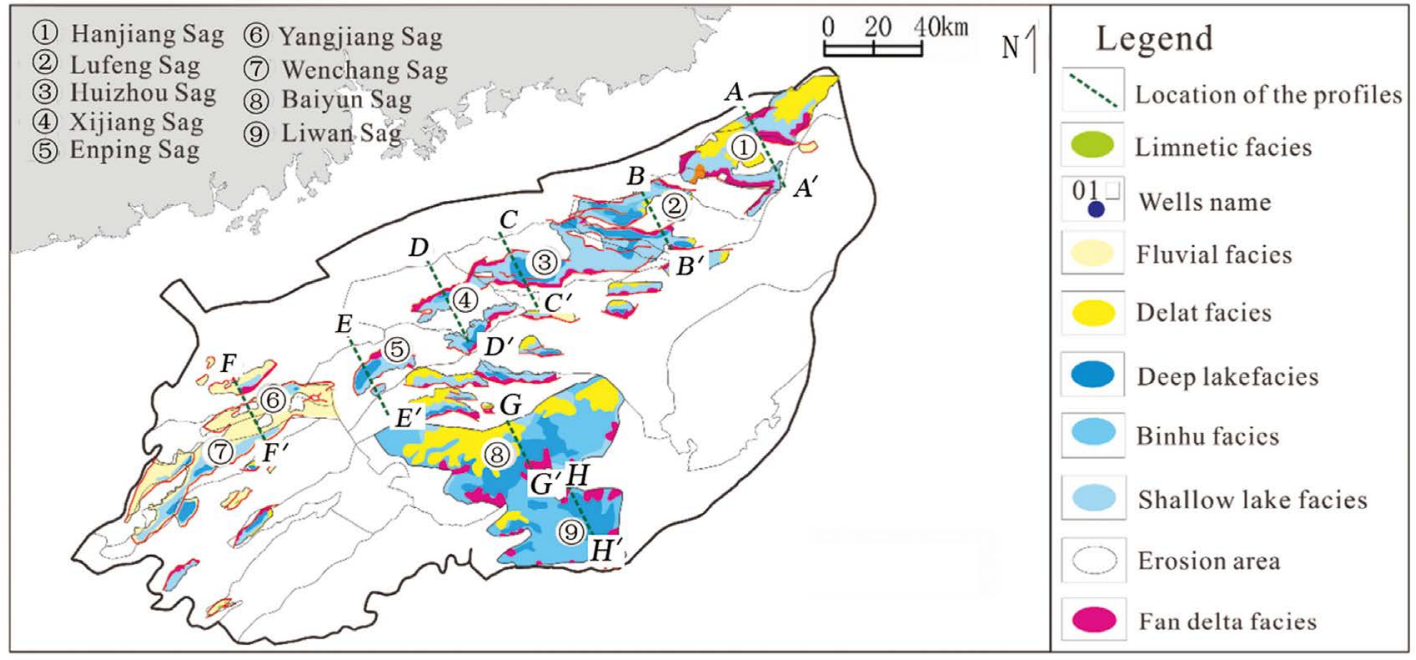

Figure 11. Sedimentary facies associations in PRMB. 


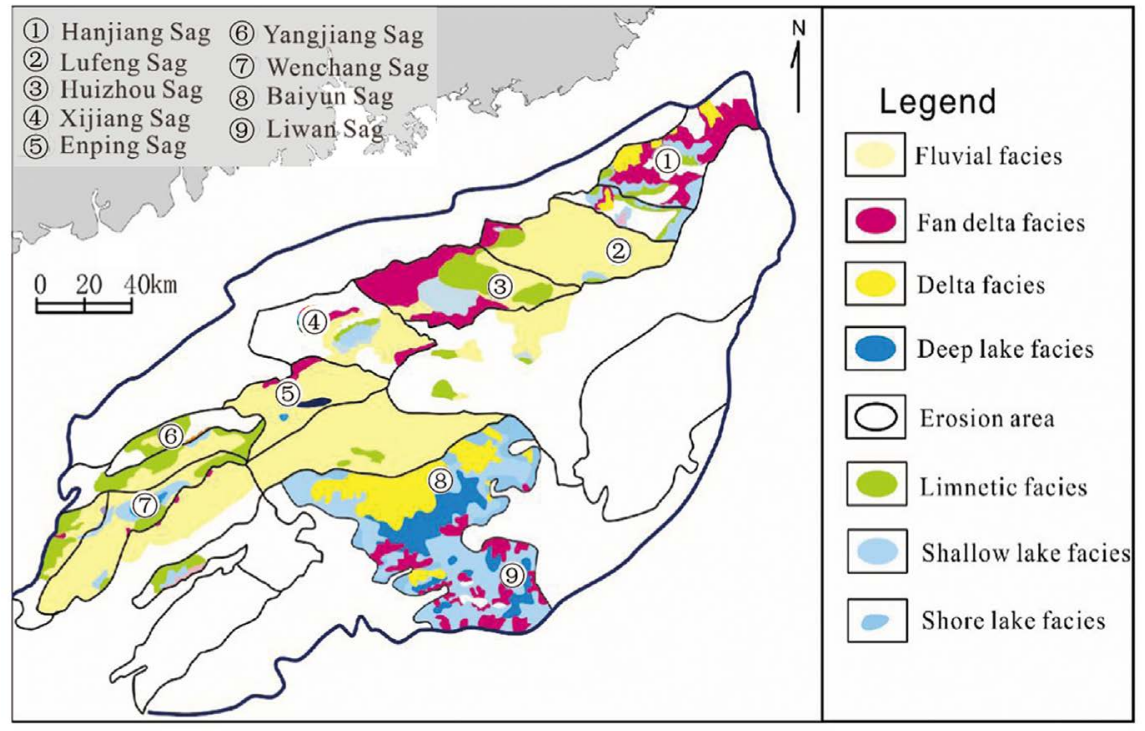

Figure 12. Sedimentary facies associations in PRMB.

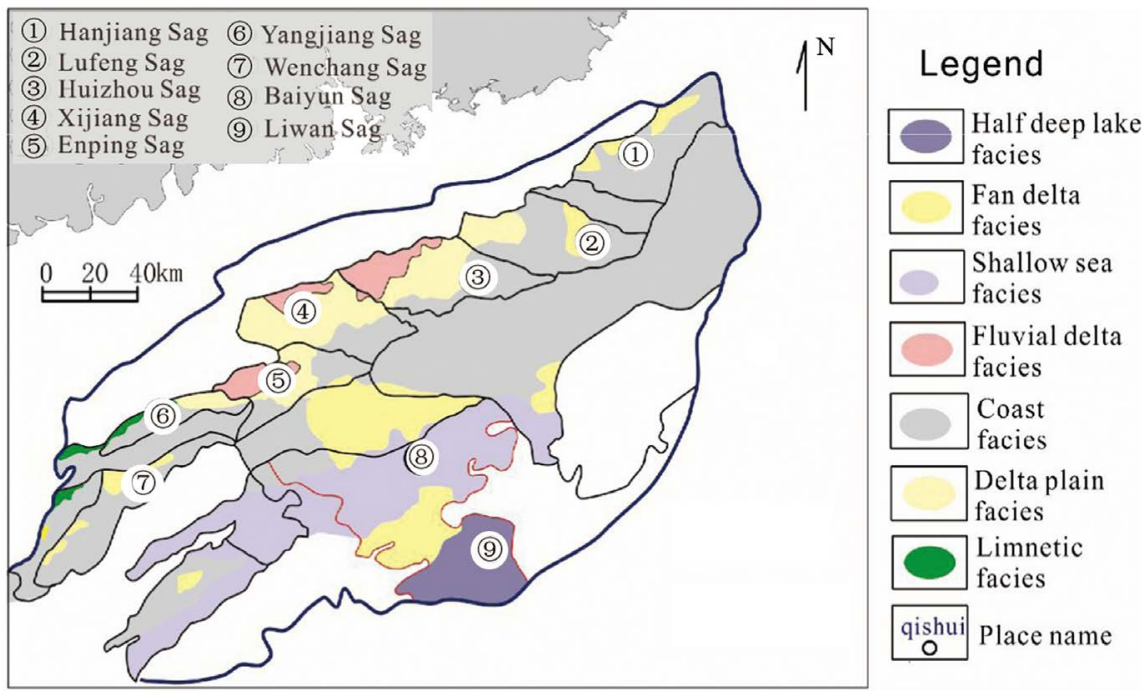

Figure 13. Sedimentary facies associations in PRMB.

\subsection{Tectonic Background of Hydrocarbon-Rich Sags}

The present regional tectonic characteristics of the northern continental margin basins are formed by mutual interactions of the Eurasian Plate, Pacific Plate, Philippine Plate, and Indian Plate [15]. Since the Mesozoic, there have been several geologic effects resulting from compressing, matching, stretching, and strike-slipping of the marginal seas of the East Asia Plate; these effects include the movement, underthrusting, and collisions of the Eurasian Plate, Pacific Plate, Philippine Plate, and Indian Plate [15]. The northern continental margin basins undergo multiple tectonic evolution activity along with the disappearance of the ancient South China Sea and the formation of the modern South China Sea [16].

During the Paleocene (approximately $65 \mathrm{Ma}$ ), the Indian Plate starts to move northwards, and the west part of the Indian Plate preliminarily converges into 
the Eurasian Plate [15]. At the same time, the Pacific Plate converges with the Eurasian Plate from northwest, and the median ridge of the Philippine Sea starts to open [17] (Figure 14(a)).

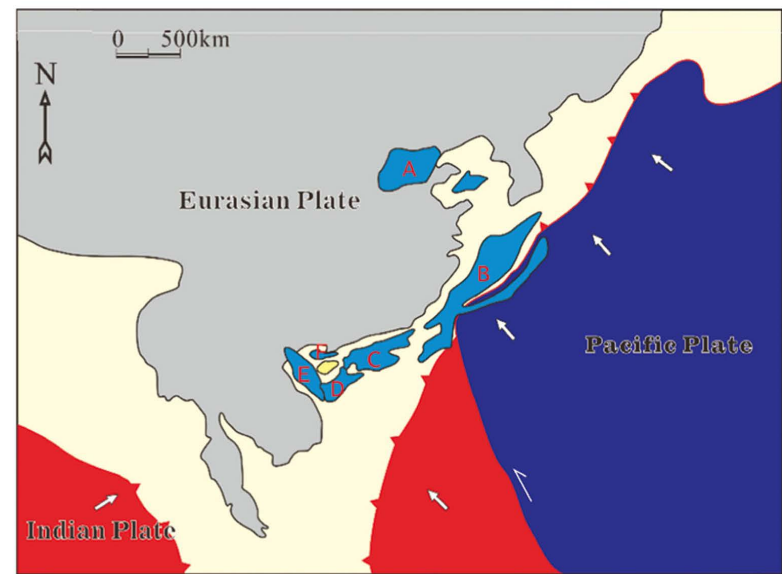

(a) $65 \mathrm{Ma}$

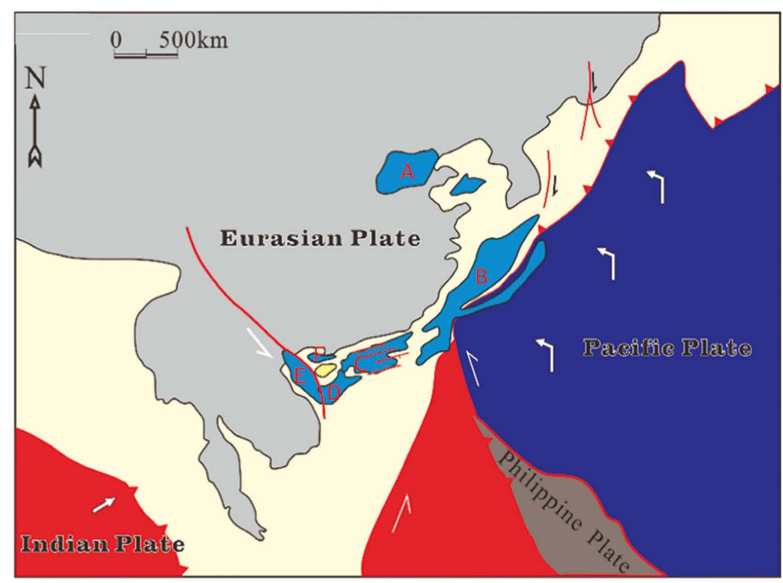

(c) $40 \mathrm{Ma}$

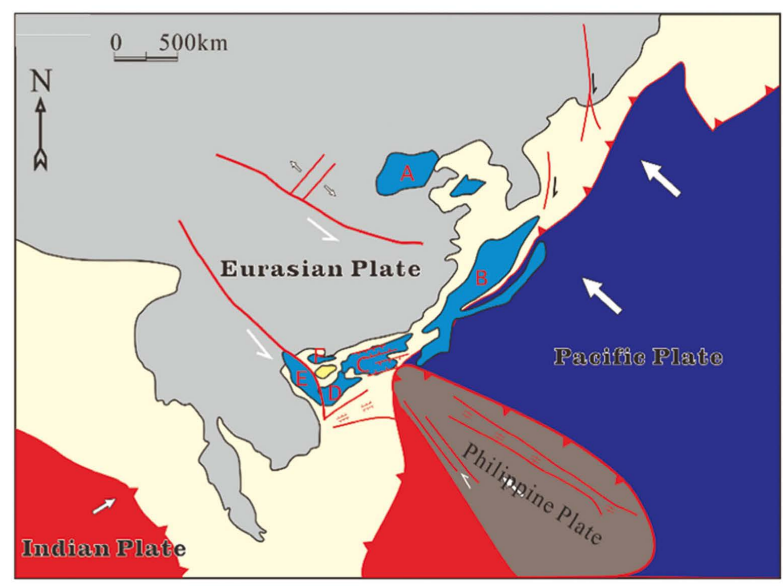

(e) $23 \mathrm{Ma}$

A Bohai Bay Basin $\square$ B East Sea Basin $\square$ C Pearl River Mouth Basin $\lceil$ normal fault $\longrightarrow$ strike slip fault $\square$ sedim

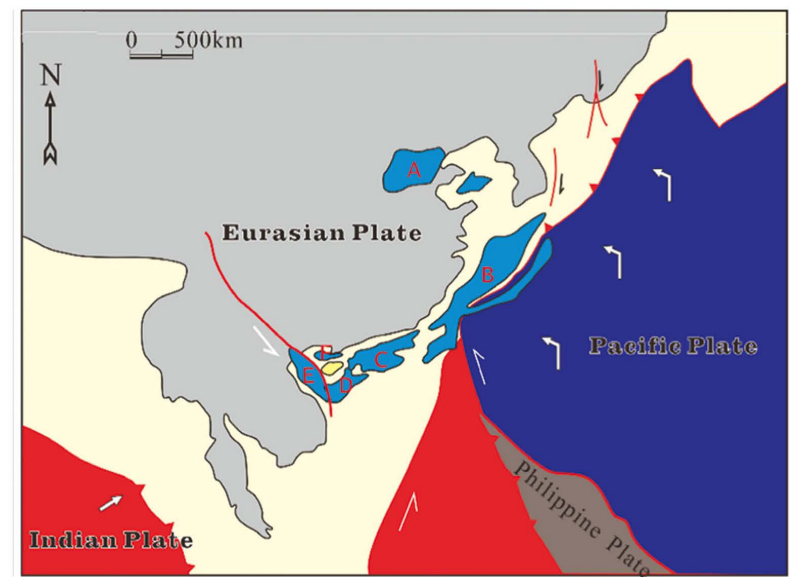

(b) $49 \mathrm{Ma}$

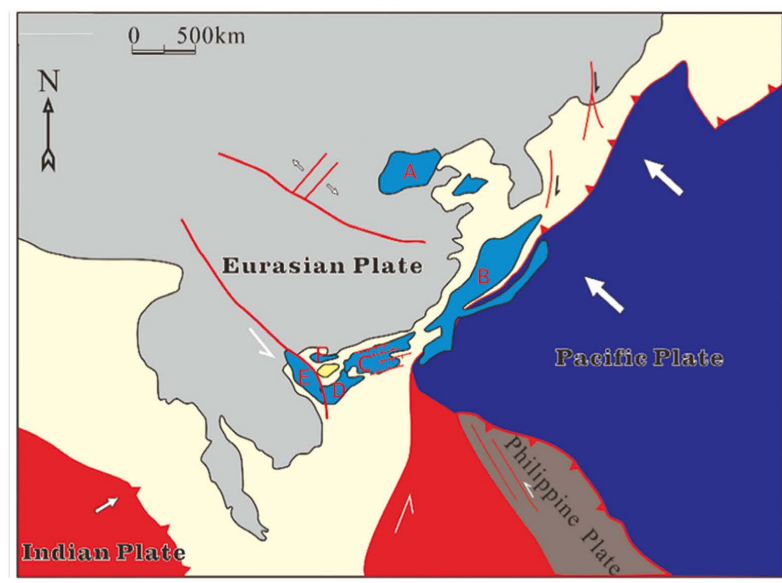

(d) $30 \mathrm{Ma}$

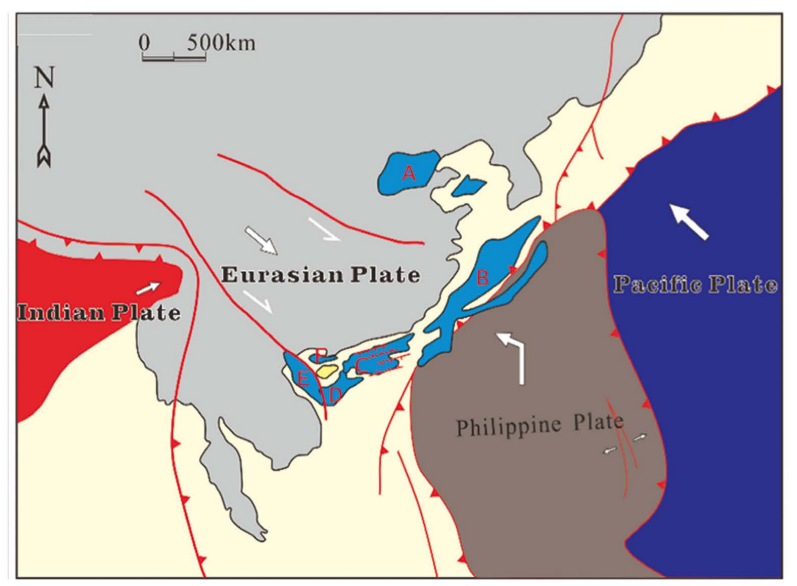

(f) now

f D Southeast Qiong Basin $\square$ E Yinggehai Basin $\square$ F Beibu Gulf Basin icntarybasin $\quad$ thrust fault $\$$ stress direction

Figure 14. Structural evolution from Cenozoic in the northern continental margin basin, South China Sea (changed from Hall R, 1996; Hall R, 2002). 
During the Paleocene-Eocene (approximately $49 \mathrm{Ma}$ ), the Philippine Plate starts underthrusting to the north. With a wedge form, the Philippine Plate inserts itself between the Pacific Plate and the Indian Plate. Therefore, with anticlockwise rotation, the Pacific Plate converged with the Eurasia Plate. Meanwhile, the Indian Plate is extensively collided with the Eurasia Plate. Controlled collectively by the Pacific Plate, the Philippine Plate, the Indian Plate and the Eurasian Plate, the western parts of the northern continental margin basins has complicated strike-slip stress fields [18] (Figure 14(b)).

During the Eocene-Oligocene (approximately $40 \mathrm{Ma}$ ), Indian Plate is slowly forced into the Eurasian Plate from the northwest. With anticlockwise rotation, Pacific Plate and Philippine Plate is closed with the Eurasian Plate. Influenced by structural processes at the tectonic scale, the northern continental margin basins experiences complicated tenso-shear stress fields, and some discordogenic faults starts to develop [19] (Figure 14(c)).

During the middle and late Oligocene (approximately $30 \mathrm{Ma}$ ), the Pacific Plate continues to underthrust beneath the Eurasian Plate. The Philippine Plate is primarily a underthrust beneath Eurasian Plate, and convergence with Pacific Plate is diminished. Because of the stress field surrounding the plate, many tectonic movements on Eurasian Plate occur including intracontinental subduction, strike-slip, tenso-shear movement, and block movement [20] (Figure $14(d))$.

During the Oligocene-Miocene (approximately $23 \mathrm{Ma}$ ), Philippine Plate is moved to the northwest and rotated anticlockwise. Therefore, the southeastern part of Eurasian Plate develops strike-slip structures. At the same time, the Indian Plate is moved into the Eurasian Plate from the northeast. Normal faults are formed in the north and the center of the northern continental margin basins due to pull-apart stresses [21] (Figure 14(e)).

From the Miocene to the present, the Philippine Plate has been pinched out from the northwest, and the Indian Plate has collided with the Eurasian Plate. Correspondingly, the direction of flow of the upper mantle is changed under the Asian continent, and meanwhile, the South China Sea starts to enlarge. Thus, the modern regional tectonic characteristics of the northern continental margin basins are formed. In addition, the northern continental margin of the South China Sea has a complicated stress field that forms classic passive continental margin basins [21] (Figure 14(f)).

Based on their properties, the northern continental margin basins can be divided into two types of basin, including continental margin straggling basins (i.e., $\mathrm{PRMB}$ and the Qiongdongnan Basin (QB)) and a continental margin strike-slip basin (i.e., the Yinggehai Basin (YB)). However, QB and YB are not studied in this work.

\subsection{Sedimentary and Structural Coevolution of the Hydrocarbon-Rich Sags}

The hydrocarbon-rich sags are developed at the rifting stage because the major tensile stress direction is approximately NW, NE or ENE. At the same time, a se- 
ries of synsedimentary faults are developed. The synsedimentary faults control this kind of paleotopography. The "half grabens" pattern produces ideal natural habitats for lacustrine deposition. This kind of paleotopography can provide a large accommodation space for many phytoplankton [22]. Gray-black mudstone and gray and linen argillaceous siltstone indicate a deep lake sedimentary environment. Against this structural background, the hydrocarbon-rich sags accumulates deep lacustrine facies, shallow lacustrine facies, delta and fan delta facies. Therefore, the fault activity controls the formation of the half graben structures, while the half graben in turn controls the distribution of lacustrine deposits. During Enping Formation stage, PRMB develops transitional sedimentation [4]. The hydrocarbon-rich sags are at the late rifting stage, but the fault activity is not so frequent as at Wenchang Formation stage. In addition, the fault activity gradually decreases because the most synsedimentary faults terminate upward in Enping Formation. With fault activity gradually decreasing, the depth of the water becomes shallow during Enping Formation stage, and this formation is deposited on the top of Wenchang Formation. Therefore, there is a sharp decrease in the amount of phytoplankton and a great increase in the amount of fern seeds and arboreal pollen. Coal and coarse-grained sandstone indicate a sedimentary environment with shallow water. Against this structural background, the hydrocarbon-rich sags accumulate delta, fluvial, limnetic, shallow lacustrine and shallow lake facies. Baiyun and Liwan Sags are dominated by shallow lake facies, fan delta facies and fluvial facies [3] [4]. Therefore, the weak fault activity influences the transitional deposition process of the transitional sedimentation in the hydrocarbon-sags during Enping Formation stage. After the deposition of Enping Formation, PRMB develops marine sedimentation [3] [4]. The hydrocarbon-rich sags are at the transition stage and the depression stage, and the fault activity becomes weaker or stopped. The faults developed during marine sedimentation are the reactivations of the faults formed during Wenchang and Enping Formation stages. Marine dinophyceae indicates a marine sedimentary environment. Against this structural background, the hydrocarbon-rich sags accumulate shallow sea and coastal plain facies [3] [4]. Therefore, the weak fault activity and depression activity control the deposition process in the hydrocarbon-rich sags.

During the rifting stage, the tectonic activity is dominated by fault activity while lacustrine sedimentation is developed. The continuous activity of the faults provides sufficient space for the lacustrine sedimentation. However, the activity of the fault is only local activity within the basin, and weak fault activity provides limited sedimentary space. In addition, basin depression involves the whole subsidence activity of basin basement [4]. Further, the depression can provide more space for seawater and marine deposition. Therefore, under the conditions of rifting-depression and depression, marine sedimentation is developed. The activity of faults can only provide the space required to deposit the lacustrine sedimentation. During the late rifting stage, fault activity is not obvious within the basin. In addition, the sedimentary space of the basin only belongs to the transi- 
tional period. The transitional sedimentation is deposited during this period. The changes in tectonic conditions correspond to different lacustrine, transition phase and marine deposition. The lacustrine sedimentation is formed under fault activity during the rifting stage. The transitional sedimentation is formed under weak fault activity during the late rifting stage. The marine sedimentation is formed under subsidence activity during the rifting-depression and depression stages.

\section{Conclusions}

Based on the above observations, the following conclusions may be drawn:

1) The present regional tectonic characteristics of PRMB are formed by mutual interactions of Eurasian Plate, Pacific Plate, Philippine Plate and Indian Plate. During the Paleocene to early Eocene and late Eocene and early Oligocene, PRMB is at the rifting stage. During the late Oligocene, PRMB is at the rifting-depression transitional stage. After the Oligocene, PRMB is at the depression stage.

2) Tectonic evolution affects the deposition process in the hydrocarbon-rich sags. The lacustrine, transitional and marine sedimentation corresponds to different tectonic conditions. During the lacustrine sedimentation stage, fault activity controls the sedimentation. During the transitional sedimentation stage, weak fault activity influences the deposition process in the hydrocarbon-rich sags. During the marine sedimentation stage, weak fault activity and depression activity control the deposition process in the hydrocarbon-rich sags.

3) The half-graben is beneficial for the formation of lacustrine source rocks, which is responsible for the hydrocarbon-rich sag. Therefore the half graben mode contributes to the hydrocarbon-rich sags.

\section{Acknowledgements}

All the data used in this study are provided by China National Offshore Oil Corporation Research Institute. Authors thank Zhigang Zhao, Zongbao Liao, and Liang Ding for the assistance of core analysis and seismic stratigraphy interpretation.

\section{Foundation}

This study is jointly supported by the National Natural Science Foundation of China (No. 41702135), the Yangtze Youth Fund (No. 2015qq33), the $13^{\text {th }}$ "Five-year" plan of the Ministry of Science and Technology of China (No. 2016ZX05037-002) and National Science and Technology Major Project (NO.2016ZX05015-006).

\section{Conflicts of Interest}

The authors declare no conflicts of interest regarding the publication of this paper. 


\section{References}

[1] Sakran, S. and Said, S.M. (2018) Structural Setting and Kinematics of Nubian Fault System, Se Western Desert, Egypt: An Example of Multi-Reactivated Intraplate Strike-Slip Faults. Journal of Structural Geology, 107, 93-108. https://doi.org/10.1016/j.jsg.2017.12.006

[2] Marsset, T., Ruffine, L., Gay, A., Ker, S. and Cauquil, E. (2018) Types of Fluid-Related Features Controlled by Sedimentary Cycles and Fault Network in Deepwater Nigeria. Marine \& Petroleum Geology, 89, 330-349. https://doi.org/10.1016/j.marpetgeo.2017.10.004

[3] Zhu, W., Huang, B., Mi, L., et al. (2009) Geochemistry, Origin and Deep-Water Exploration Potential of Natural Gases in the Pearl River Mouth and Qiongdongnan Basins, South China Sea. AAPG Bulletin, 93, 741-761. https://doi.org/10.1306/02170908099

[4] Wu, Z., Zhu, W., Shao, L. and Xu, C. (2016) Sedimentary Facies and the Rifting Process during the Late Cretaceous to Early Oligocene in the Northern Continental Margin, South China Sea. Interpretation, 4, 33-45. https://doi.org/10.1190/INT-2015-0163.1

[5] Peng, J., Pang, X., Shi, H., Peng, H., Xiao, S., Yu, Q., et al. (2016) Hydrocarbon Generation and Expulsion Characteristics of Eocene Source Rocks in the Huilu Area, Northern Pear River Mouth Basin, South China Sea: Implications for Tight Oil Potential. Marine \& Petroleum Geology, 72, 463-487.

https://doi.org/10.1016/j.marpetgeo.2016.02.006

[6] Wang, X., Qian, J., Collett, T. S., Shi, H., Yang, S., Yan, C., et al. (2016) Characterization of Gas Hydrate Distribution Using Conventional 3D Seismic Data in the Pearl River Mouth Basin, South China Sea. Interpretation, 4, 25-37.

https://doi.org/10.1190/INT-2015-0020.1

[7] Gan, H.J., Tian, H., Huang, B.J., Wilkins, R.W.T., Tang, Y.C. and Xiao, X.M. (2009) Generation and Accumulation of Oil and Condensates in the Wenchang a Sag, Western Pearl River Mouth Basin, South China Sea. Geofluids, 9, 275-286. https://doi.org/10.1111/j.1468-8123.2009.00264.x

[8] Jiang, Z., Zhu, J., Deng, H. and Hou, D. (2012) Petroleum System and Hydrocarbon Accumulation Characteristics in the Wenchang and Enping Formations in the Huizhou Sag, Pearl River Mouth Basin, China. Energy Exploration \& Exploitation, 30, 351-371. https://doi.org/10.1260/0144-5987.30.3.351

[9] Hall, R. (2002) Cenozoic Geological and Plate Tectonic Evolution of SE Asia and the SW Pacific: Computer-Based Reconstructions, Model and Animations. Journal of Asian Earth Sciences, 20, 353-431. https://doi.org/10.1016/S1367-9120(01)00069-4

[10] Zheng, W. and Deng, H. (2012) High-Resolution Sequence Stratigraphic Division and Distribution of Tidal Deposits in the Zhuhai Formation, Huizhou Sag, Pearl River Mouth Basin, South China Sea. Geological Magazine, 149, 722-728. https://doi.org/10.1017/S0016756811000768

[11] Liu, Y., Wu, H.C., Zhang, S.H., Fang, N.Q., Jiang, Z.L. and Yang, T.S. (2012) Cyclostratigraphy Research on the Hanjiang-Wanshan Formations in the Zhu I Depression, Pearl River Mouth Basin. Earth Science. Journal of China University of Geosciences, 37, 411-423. (In Chinese)

[12] Zhu, W., Zhang, G. and Gao, L. (2008) Geological Characteristics and Exploration Objectives of Hydrocarbons in the Northern Continental Margin Basin of South China Sea. Acta Petrolei Sinica, 29, 1-9. (In Chinese) 
[13] Xu, Q., Shi, W., Xie, X., et al. (2018) Inversion and Propagation of the Late Paleozoic Porjianghaizi Fault (North Ordos Basin, China): Controls on Sedimentation and Gas Accumulations. Marine \& Petroleum Geology, 91, 706-722. https://doi.org/10.1016/j.marpetgeo.2018.02.003

[14] Wellman, C.H. and Gray, J. (2000) The Microfossil Record of Early Land Plants. Philosophical Transactions of the Royal Society of London B: Biological Sciences, 355, 717-732. https://doi.org/10.1098/rstb.2000.0612

[15] Fan, S. and Liao, K. (2005) Changes of Cenozoic Paleo-Environment in Northern South China Sea. Journal of Guangxi Academy of Sciences, 21, 51-55. (In Chinese)

[16] Wang, J. and Liu (2011) Tectonic-Sedimentary Responses to the Second Episode of the Zhu-Qiong Movement in the Enping Depression, Pearl River Mouth Basin and Its Regional Tectonic Significance. Acta Petrolei Sinica, 32, 588-595.

[17] Cullen, A., Reemst, P., Henstra, G., et al. (2010) Rifting of the South China Sea: New Perspectives. Petroleum Geoscience, 16, 273-282. https://doi.org/10.1144/1354-079309-908

[18] Luan, X.W., Peng, X.C. and Qiu, Y. (2009) Tectonic Control on the Formation of High-Deposition-Rate Sediment Drift in the Northern Slope of the South China Sea. Geoscience, 23, 183-199. (In Chinese)

[19] Li, C., et al. (2009) Opening of the South China Sea and Its Implications for Southeast Asian Tectonics since the Late Mesozoic. Advances in Earth Science, 24, 1339-1351.

[20] He, L. (1982) Tectonic Evolution of the Lithosphere Plates and Some Features of the Sedimentary Distribution in Cenozoic Era in South China Sea. Marine Geology \& Quaternary Geology, 2, 16-23. (In Chinese)

[21] Yan, Q., Shi, X. and Castillo, P.R. (2014) The Late Mesozoic-Cenozoic Tectonic Evolution of the South China Sea: A Petrologic Perspective. Journal of Asian Earth Sciences, 85, 178-201. https://doi.org/10.1016/j.jseaes.2014.02.005

[22] Sarmento, H., Isumbisho, M. and Descy, J.P. (2006) Phytoplankton Ecology of Lake Kivu (Eastern Africa). Journal of Plankton Research, 28, 815-829. https://doi.org/10.1093/plankt/fbl017 